\title{
SHAKESPEARE AND SOVEREIGNTY: A BIOPOLITICAL READING OF MACBETH
}

\author{
Deniz KARACA $A^{1}$
}

\begin{abstract}
Biopolitics has brought new perspectives on power relations in society with the conceptualization of Michelle Foucault. Although the history of the concept goes back to the past, biopolitics has been used to analyze the power and social power relations in many areas from body control to population politics, thanks to Foucault. Italian philosopher Giorgio Agamben has carried the concept of biopolitics to another point and contributed to the concept of biopolitics with his studies on sovereignty. Unlike Foucault, who claims that biopolitics is modern thought, Agamben traces biopolitics in ancient texts. In his book Homo Sacer, Agamben allows us to reflect on the limits of sovereignty with the concept of bare life. Agamben searches for the holy man who can be killed but not sacrificed in Roman Law and makes analyzes social power relations and sovereignty through this concept. This article aims to make a biopolitical reading of William Shakespeare's play Macbeth, based on Agamben's analysis of the Homo Sacer. As Macbeth kills King Duncan and becomes king himself, his struggle with the ghost of sovereignty begins. While this article seeks the reasons for Macbeth's inability to legitimize his power as the possessor of sovereignty and power in Elizabethan political theology and ideological structure, it reveals, in a biopolitical reading, that Macbeth has fallen into the position of the Homo Sacer, who cannot be sacrificed but is legitimate to be killed, that the sovereign is not above sovereignty, and that the king's mystical existence is separated from bodily existence. It is intended to analyze that with the killing of the king, Macbeth seeks to retain sovereignty while trying to cope with the pain of breaking the sacred order as an object of the dominant ideology. In this article, the reason why Macbeth's sovereignty cannot be legitimized is discussed based on the argument that power has a productive rather than an oppressive nature while examining how his position has transformed into the Homo Sacer in Agamben's theory.
\end{abstract}

Keywords: Biopolitics, Sovereignty, Macbeth, Homo Sacer, Legitimacy

\footnotetext{
${ }^{1}$ Doktora Öğrencisi, İstanbul Aydın Üniversitesi, denizk@stu.aydin.edu.tr, ORCID:0000-0003-4961-0443
} 
İnceleme / Analysis

\section{SHAKESPEARE VE EGEMENLİK: MACBETH'İN BİYOPOLİTİK BİR OKUMASI}

\section{$\ddot{O} z$}

Biyopolitika Michelle Foucault'nun kavramsallaştırmasıyla beraber toplumdaki güç ilişkilerine ilişkin yeni bakış açıları kazandırmıştır. Kavramın tarihi eskiye uzansa da biyopolitika Foucault sayesinde beden kontrolünden nüfus politikalarına kadar pek çok alanda iktidar ve toplumsal güç ilişkilerini çözümlemek için kullanılmıştır. İtalyan filozof Giorgio Agamben biyopolitika kavramını başka bir noktaya taşıyarak egemenlik üzerine çalışmalarıyla biyopolitika kavramına katkı sağlamıştır. Biyopolitikanın modern bir düşünce olduğunu öne süren Foucault'nun aksine Agamben biyopolitikanın izini antik metinlerde sürer. Kutsal İnsan adlı eserinde Agamben, çılak hayat kavramsallaştırmasıyla egemenliğin sinırları üzerine düşünmemizi sağlar. Agamben öldürülebilen ama kurban edilemeyen kutsal insanı Roma Hukuku'nda arar ve bu kavram üzerinden toplumsal güç ilişkileri ve egemenlik üzerine analizler yapar. Bu makalede Agamben'in Kutsal İnsan çözümlemesinden hareketle William Shakespeare'in Macbeth oyununun biyopolitik bir okumasını yapmak amaçlanmıştır. Macbeth'in kral Duncan'ı öldürmesiyle ve kendinin kral olmasiyla beraber egemenlik hayaletiyle mücadelesi başlar. Bu makale Macbeth'in egemenliğin ve gücün sahibi olarak iktidarını meşrulaştıramamasının sebeplerini Elizabeth dönemi politik teolojisinde ve ideolojik yapisinda ararken, biyopolitik bir okumayla Macbeth'in kurban edilemeyen ama öldürülmesi meşru olan Kutsal İnsan pozisyonuna düştüğünü, egemenin egemenliğin üstünde olmadığını ve kralın mistik varoluşunun bedensel varoluştan ayrıllısını analiz etmek amaçlanmıştır. Macbeth kralı öldürmesiyle, bir taraftan egemen ideolojinin bir nesnesi olarak kutsal düzeni bozmanın sancılarıyla baş etmeye çalışırken diğer taraftan egemenliği elinde tutmanın yollarını arar. Bu makalede, Macbeth'in egemenliğini meşrulaştıramamasının sebebi gücün baskıcı değil üretken bir doğası olduğu savından hareketle tartışılırken, kendi pozisyonunun Agamben'in teorisindeki kutsal insana nasıl dönüştüğü irdelenmektedir.

Anahtar Kelimeler: Biyopolitika, Egemenlik, Macbeth, Kutsal ,nsan, Meşruiyet

\section{Introduction}

OLD MAN: 'Tis unnatural,

Even like the deed that's done. (Shakespeare, 1990, p. 14)

When depicting the atmosphere after the murder of King Duncan in William Shakespeare's tragedy Macbeth, old man associates the act of murder with the unnatural weather conditions and by doing so he reflects the latent social belief on the metaphysical, mystical existence of the king and its symbolic order. His association with the weather conditions and the murder of the king creates the question that what was unnatural about this murder. This question is the pivotal matter of this paper. By taking the ideas of Giorgio Agamben and Michelle Foucault on biopolitics and sovereignty, the article seeks a biopolitical reading of Macbeth.

Biopolitics is a modern thought that is mostly shaped by the ideas of Michelle Foucault on the power and authority that focus on modern power and governmentality. However, it is fruitful to comprehend the idea of power which is helpful to analyze Shakespeare's perspective. Foucault's ideas on power bring us an understanding and epistemological break with the classical 
idea of power which is based on mostly the oppressive state authority. Foucault, unlike the traditional belief that focuses on the repressive quality of the state and power, sees the power as a productive and more complex conception. This decentralized conceptualization of power is putting power relations on a more productive ground rather than the repressive understanding of the power. In Society Must Be Defended, Foucault explains his conceptualization as the power:

is never appropriated in the way that wealth or a commodity can be appropriated. Power functions. Power is exercised through networks, and individuals do not simply circulate in those networks; they are in a position to both submit to and exercise this power. They are never the inert or consenting targets of power; they are always its relays. In other words, power passes through individuals. It is not applied to them. (2003: p. 29)

Foucault suggests a "radical departure from previous modes of conceiving power and cannot be easily integrated with previous ideas, as power is diffuse rather than concentrated, embodied and enacted rather than possessed, discursive rather than purely coercive, and constitutes agents rather than being deployed by them" (Gaventa, 2003: p. 1). He sees power as an embodiment of an ideology and discourse, and it exercises through creating "régime of truth" (Rabinow, 1991: p. 131). For Foucault what creates the legitimacy and makes the society accept it "is simply the fact that it doesn't only weigh on us as a force that says no, but that it traverses and produces things, it induces pleasure, forms knowledge, produces discourse" (Interview, "Truth \& Power": p. 119). Thus, what constitutes the strength of power is its ability to create an ideological discourse that is a ground to shape the society along with a Truth.

Truth is a thing of this world: it is produced only by multiple forms of constraint. And it induces regular effects of power. Each society has its régime of truth, its 'general politics of truth: that is, the types of discourses which it accepts and makes function as true; the mechanisms and instances which enable one to distinguish true and false statements, the means by which each is sanctioned; the techniques and procedures accorded value in the acquisition of truth; the status of those who are charged with saying what counts as true (Interview, “Truth and Power": p. 131).

Biopolitics is first used by Foucault in his works The History of Sexuality (1976) and Society Must Be Defended (1976). His conceptualization is based on his perspective on discipline and power relations in modern society as he states that "man remained what he was for Aristotle: a living being with the additional capacity for a political existence; modern man is an animal whose politics places his existence as a living being in question" (1973: p.143). With the atomization of the human, the exercise of power on the human body transforms into a more complex form which is the ability to create control over life and death norms of the subjects transforms in modern society to the complex sovereignty politics to design the biological 
existence of individuals. As he states in Society Must Be Defended (1976) sovereignty change to form of controlling life rather than a repressive use of power:

I think that one of the greatest transformations political right underwent in the nineteenth century was precisely that, I wouldn't say exactly sovereignty's old right- to take life or let life- was replaced, but it came to be complemented by a new right which does not erase the old right but which does penetrate it, permeate it. This is the right, or rather precisely the opposite right. It is the power to 'make' live and 'let' die. The right of sovereignty was the right to take life or let live. And then this new right is established: the right to make life and to let die. (Foucault, 1976: p. 241)

Briefly, Foucault creates us a more comprehensive insight that will be beneficial to read the ideological discourse which Shakespeare uses as a frame for power. The other significant figure that contributes to the area is Italian philosopher Giorgio Agamben with his theory of sovereignty. Giorgio Agamben in his work Homo Sacer seeks the true nature of power and sovereignty. He starts his journey on the politics of sovereignty by taking a base on the ideas of political philosopher Carl Schmitt ?? and his definition of sovereignty that claims, "the sovereign is the one who decides on the state of exception" (1985: p. 11). Thus, the sovereign is the one that decides the life and death norms of others, but on the other hand, there seem to be problematic arises from this argument which is the sovereign is an exception to the rule of the sovereign himself is a subject to the rule as the one who makes the rule effective. Basing the argument, Agamben traces back to ancient Greek that distinguishes political life and animal life to survey to map the sovereignty. Dividing the human life into two categories "bios" and "zoe", Agamben theorizes Homo Sacer as the one who: "has been excluded from the religious community and all political life: he cannot participate in the rites of his gens, nor $[\ldots]$ can he perform any juridically valid act.” (Agamben, 1998: p. 183). However, the most striking side of the definition is defining him as a living corpse as Agamben continuous his definition: "his entire existence is reduced to a bare life stripped of every right because anyone can kill him without committing homicide; he can save himself only in perpetual flight or a foreign land." (1998: p. 183). Thus, Homo Sacer's reduced position to an exception to the rule is the core of Agamben's theory.

Agamben (1998) commenting on political theorist Carl Shmitt's axiom that "The rule proves nothing; the exception proves everything: It confirms not only the rule but also its existence, which derives only from the exception."(p. 15) theorizes the "state of exception" that is the ground that determines the norm, the area between the law and the political: the state of exception is not a special kind of law (like the law of war); rather, in so far as it is a suspension of 
the juridical order itself, it defines law's threshold or limit concept" (Agamben, 1998: p. 4). So, this state is for Agamben (1998) is a

threshold that guarantees the articulation between an inside and an outside, or between anomie and the juridical context, by a law that is in force in its suspension; it is, rather, a zone of absolute indeterminacy between anomie and law, in which [life and law] are caught up in a single catastrophe (p. 57).

Consequently, categorizing power and sovereignty as something only coercive detracts us from a complete understanding of these concepts, to comprehend and produce meaningful analysis on how Shakespeare sees these concepts, it is essential to focus on the productive power of the power and sovereignty. As it is mentioned above Foucault suggests a different concept of truth focusing on its ability to produce knowledge and truth, according to Foucault truth "is to be understood as a system of ordered procedures for the production, regulation, distribution, circulation and operation of statements." (Interview, "Truth and Power": p. 133) and he continuous that it "is linked in a circular relation with systems of power which produce and sustain it, and to effects of power which it induces and which extend it. A 'regime' of truth". (Interview, "Truth and Power": p. 133). The truth regime is the system that constructs the ideological consciousness of society, not only political but also regulates the life and moral values of the society.

\section{Problem of Sovereignty in Macbeth}

Shakespeare, as a member and an intellectual of the society, is both receiver and producer of the truth regime of the society. His political perspective that is reflected in his tragedies was the dominant ideology which produces legitimacy of the order in the society and Shakespeare is both a discourse producer of this ideology and his ideological framework is also shaped by the truth regime of the society. In Macbeth it is easy to see the effects of this ideology, in Foucauldian sense the truth regime of Elizabethan society, when Macbeth tries to persuade himself to decision acting to take the throne, he hesitates with his consciousness of obedience to the truth regime. He has two hesitations in the beginning; killing a king which means breaking the order of God, and the second one is that the social norms which is also a part of the truth regime; killing the guest and also kin. "First, as I am his kinsman and his subject, Strong both against the deed; then, as his host" (Shakespeare, 1990: p. 118). Regicide and parricide are the most terrible deeds of Elizabethan society and these are both committed by Macbeth. He breaks the order of the universe and social order in other words he destroys the truth regime. Thus, 
Duncan's authority does not take its roots from his powerful army or state power, it comes from the deep belief of his being representative of God and being the legitimate king of the country that's why Macbeth feels guilty even to think about killing the king, his real fear is to destroy the order not to kill a man. Even to think about killing the king is treason to nature:

If good, why do I yield to that suggestion

Whose horrid image doth unfix my hair

And make my seated heart knock at my ribs

Against the use of nature? Present fears

Are less than horrible imaginings.

My thought, whose murder yet is but fantastical,

Shakes so my single state of man

That function is smothered in surmise

And nothing is but what is not. (1990: p.155)

The other problem arouses from the murder of the king is a king never dies as it is the representation of the God in the world, some mystical qualities are attributed to the king. Benjamin Parris defines the two bodies of the king which are material and mystical as "the king was held to possess a natural body common to all humans, as well as a mystical "super body" that perpetuates the life of the state and lends an aura of divine perfection to the sovereign.” (2012: p. 1). Thus, killing the material body of the king is never enough to get rid of the ghost of sovereignty and legitimacy. Immortality of the king does not mean physical death, but it comes from the continuity "in the state of royal demise, there is no event of complete or final death since the body politic remains an ideal and continuous presence." (Parris, 2012: p. 7). This belief derived from Christian theology as Kantorowicz suggests: "the king's two bodies is an offshoot of Christian theological thought and, consequently, stands as a landmark of Christian political theology"(1997: p. 506). Commenting on this immortality of the sovereign Agamben draws a parallelism between this immortal body and homo sacer: "the metaphor of the political body appears no longer as the symbol of the perpetuity of dignitas, but rather as the cipher of the absolute and inhuman character of sovereignty" (1998: p. 67). In addition to this immortality, the king is out of law according to Agamben like homo sacer as he states; "Yet the other defining characteristic of homo sacer's life, that is, his unsacrificeability according to the forms prescribed by the rite of the law, is also to be found in the person of the sovereign.” (p. 68). He suggests that the king is out of the law, in relation with his mystical body: 
When the Jacobins suggested, during the discussions of the 1792 convention, that the king be executed without trial, they merely brought the principle of the unsacrificeability of sacred life to the most extreme point of its development, remaining absolutely faithful (though most likely they did not realize it) to the arcanum according to which sacred life may be killed by anyone without committing homicide, but never submitted to sanctioned forms of execution. (Agamben 1998: p. 68)

Macbeth kills Duncan when he sleeps as sleeping can be seen as a human deed, it is the king's material body function so murder should be done as it is an act to the material body of the king. Even though Macbeth knows he kills the king, he even wants to hide this from his consciousness, his ration as the murder of the king as mentioned above cannot be a part of rational thought or law in a sense: "To know my deed, 'twere best not know myself." (p. 130). Macbeth knows that he does not only kills a person, but the divine order and this deed follows him "Still it cried, "Sleep no more!" to all the house. "Glamis hath murdered sleep, and therefore Cawdor Shall sleep no more. Macbeth shall sleep no more" (p. 128).

Macbeth is haunted by the ghost of sovereignty as Derrida explains in Specters of Marx: "spectral someone other looks at us, we feel ourselves being looked at by it, outside of any synchrony, even before and beyond any look on our part, according to an absolute anteriority" (2006: p. 6). Macbeth cannot escape from the gaze of the ghost of sovereignty as the mystical body of the king never dies.

Is this a dagger, which I see before me,

The handle toward my hand? Come, let me clutch thee.

I have thee not, and yet I see thee still.

Art thou not fatal vision, sensible

To feeling as to sight? Or art thou but

A dagger of the mind (p. 124)

Macbeth while struggling with the ghost of sovereignty "all the perfumes of Arabia will not sweeten this little hand." (p. 176), he also needs to rule the country as the new king, in this point, the problem of legitimacy arouses "What is this That rises like the issue of a king And wears upon his baby-brow the round And top of sovereignty?" (p. 174). He needs to rule the country but here as our biopolitical reading suggests with a Foucauldian perspective repressive authority cannot resist without a powerful discourse. as Deleuze and Guattari suggest 
"sovereignty only rules over what it is capable of interiorizing" (1987: p. 40). Thus, Macbeth as a subject of the society his political consciousness is constructed, though killing the king he cannot justify his actions, as he cannot justify his legitimacy, he cannot persuade society so his only chance to try to persuade by violence. The legitimacy problem of Macbeth according to Benjamin Parris is caused by his actions against the sovereign sleep:

"The crisis of sovereignty in Macbeth stems from the death of a sleeping king, but Macbeth's insomnia more emphatically punctuates the self-annihilating consequences of an assault on sovereign sleep. The centrality of sleep in Macbeth thus elaborates key premises of Hamlet, as Macbeth finds himself guilty of having "murders sleep" itself which is how the disembodied voice of judgment names his transgression" (2012: p. 41).

Macbeth by killing King Duncan is responsible for destroying the metaphysical existence of the king. The paradox here is when Macbeth kills the king, he breaks the sacred life of the king; however, his act also suggests another problem that is he with his murder at the same time destroys his legitimacy. Macbeth is haunted by the murder of sleep which is killing the sacred body gives way to his execution as his sacred life as a king is not secure and his position is open to the murder. Benjamin Parris sees the suggestion of the play as:

"If sleep can be murdered then the play suggests it has a body with a strange life of its own, which carries a holly valence in the case of sovereign sleep. Macbeth's supposedly sovereign body and corresponds directly to the loss of political authority that culminates in his death. Macbeth denied sleep and denied the investiture of the sacred life that ostensibly secures sovereign power. His situation thus affirms an intimacy between holiness and sovereign sleep that is grounded in the physical restoration of the body natural while it also underscores the heinous character of Macbeth's actions. The guilt of Duncan's murder takes on the substantial character of bodily humour that fuses Macbeth, becoming an insistent presence that surges and swells like "multitudinous seas" stained red with blood." (2012: p. 123)

Macbeth laments for a world that the murder can be left unpunished as he takes the throne and has the power upon his subjects as a king with a repressive power. However, he is haunted by the ghosts of his victims because he is not a legitimate king and his act of murdering the sovereign king in other words destroying the sacred life of the king leads to his being killed without punishment as he, himself destroyed the order. When he kills the king he becomes the homo sacer.

Blood hath been shed ere now, i'th'olden time,

Ere humane statute purged the gentle weal; 
Ay, and since too, murders have been performed

Too terrible for the ear. The times has been

That, when the brains were out, the man would die,

And there an end; but now they rise again,

With twenty mortal murders on their crowns,

And push us from our stools. This is more strange

Than such a murder is. (p. 157)

\section{Conclusion}

His legitimacy problem reduces his being to homo sacer, which can be killed by anybody and it is not defined as murder. When he takes the throne, his all being reduced to this state, he will be killed and as he is not a legitimate king and murderer of the king, his being killed will be left unpunished. Here there arouses another paradoxical situation, as Macbeth is a king, his killing can be deemed as an act of sovereignty. He represents the material being of the king with his repressive power and throne, but his mystical body is missing as he is not the legitimate king so his being killed is not a murder of the king.

In a society, sovereignty determines the state of exception, unlike Carl Schmitt's idea that sovereign's power to determine the life and death of the people in other words state of exception. Unlike his idea sovereign himself is subject to sovereignty and social norms. To conclude, as a biopolitical reading Macbeth as a sovereign cannot justify his being here as he is subject to the dominant ideology itself, ideology as a productive power designates the society in an order and it is productive rather than repressive and it design and produce the knowledge that people think, Macbeth as a subject to the rule cannot change the rule and as a sovereign, he is not an except, on to the rule itself.

\section{References}

Althusser, L. (1978). Lenin and Philosophy. (Trans. By Ben Brewster). New York: Monthly Review Press.

Agamben, G. (1998). Homo Sacer: Sovereign Power and Bare Life. (Translated by D. Heller-Roazen.) Stanford, California: Stanford University Press. 
Deleuze, G, and Guattari, F. (1987). A Thousand Plateaus. (Trans. Brian Massumi). Minneapolis: University of Minnesota Press.

Derrida, J. (2006). Spectres of Marx, (trans. by Peggy Kamuf). New York, Routledge Classics.

Foucault, M. (1980). Selected Interviews and Other Writings 1972-1977, ed. Colin Gordon. New York: Pantheon.

Foucault, M. (2003). Society Must Be Defended: Lectures at the Collège de France 1975-1976. ed. Mauro Bertani and Alessandro Fontana. (trans. David Macey). New York: Picador.

Foucault, Michelle (1998) The History of Sexuality: The Will to Knowledge, London, Penguin.

Kantorowicz, E. (1997). The Two Bodies of the King: A Study in Medieval Political Theology. New Haven, Princeton Univ. Press.

Shakespeare, W. (1990). Macbeth. New York, Oxford University Press.

Schmitt, C. (1985). Political Theology: Four Chapters on the Concept of Sovereignty, (trans. George Schwab), Cambridge, Mass.; London: MIT Press.

Parris, B. (2012). "The body is with the King, but the King is not with the body": Sovereign Sleep in Hamlet and Macbeth, Shakespeare Studies, ed Susan Zimmerman, Rosemont Publishing.

Rabinow, P. (1991) The Foucault Reader: An Introduction to Foucault's Thought, London, Penguin. 